\title{
PENGARUH APLIKASI BIOCHAR DAN PEMUPUKAN NITROGEN TERHADAP KETERSEDIAAN NPK TANAH PADA PERTANAMAN JAGUNG MANIS (Zea mays L.)
}

\section{THE EFFECT OF BIOCHAR APPLICATION AND NITROGEN FERTILIZING ON THE AVAILABILITY OF SOIL NPK TOWARD SWEET CORN (Zea mays L.) AGRICULTURE}

\author{
Rumse Fitriana Sirait ${ }^{1}$, Sarno $^{2)}$, Nur Afni Afrianti ${ }^{2)}$ dan Ainin Niswati ${ }^{2)}$ \\ Jurusan Agroteknologi, Fakultas Pertanian, Universitas Lampung, \\ J1. Prof. Dr. Sumantri Brojonegoro No. 1, Bandar Lampung 35145 \\ Email: fitrianasirait65@gmail.com
}

\begin{abstract}
Corn is the second food commodity that has high demand but has low production. Low soil fertility causes inappropriate soil management. Therefore, the efforts to improve soil fertility with the addition of biochar and proper $N$ fertilization should be made. This research aims to study the effect of biochar on soil NPK availability toward sweet corn, to study the effect of N fertilization toward soil NPK availability on sweet corn, and to study the effect of interaction between biochar and N fertilization on soil NPK availability toward sweet corn plants. This research was conducted at the Unila Integrated Field, Bandar Lampung from January to September 2017. The research was designed with a factorial Completely Randomized Design (CRD) with two factors and three replications. The first factor is the biochar dose, namely: 0; 2.5 and $5 \mathrm{th} \mathrm{h}^{-1}$. The second factor is the dose of $N$ fertilizer which is $0 ; 45 ; 90$ and $135 \mathrm{~kg} \mathrm{~N}$ $h^{-1}$. Data homogeneity were tested by using Bartlett Test while data additivity were tested by using Tukey Test. Data were processed by using analysis of variance and continued with Honest Significant Difference test at 1\% significance level. The results showed that biochar administration had a very significant effect on the availability of $N, P$ and $K$ nutrients in the soil, very significant effect toward the soil C-organic content and no significant effect on soil $\mathrm{pH}$. $N$ fertilization has a very significant effect on the availability of $N, P, K$ and soil $p H$ and does not significantly affect soil $C$-organic content. There was a very real interaction between the administration of biochar and $N$ fertilizer toward the availability of $N$ and $K$ nutrients, but did not interact significantly with the P nutrient content in the soil. The optimum dose of biochar administration is $2.5 \mathrm{tha}^{-1}$, while the dose of $\mathrm{N}$ fertilizer is 45 and $90 \mathrm{~kg} \mathrm{~N} \mathrm{ha}$.
\end{abstract}

Keywords: biochar, sweet corn, availability of $N, P$ and $K$ nutrients and $N$ fertilization.

\begin{abstract}
ABSTRAK
Jagung merupakan komoditas pangan kedua yang memiliki permintaan tinggi yang tidak diimbangi dengan produksi yang rendah. Kesuburan tanah yang rendah menyebabkan pengelolaan tanah yang tidak sesuai sehingga perlu dilakukan usaha untuk memperbaiki kesuburan tanah dengan penambahan biochar dan pemupukan $\mathrm{N}$ yang tepat. Penelitian ini bertujuan untuk: mempelajari pengaruh biochar terhadap ketersediaan NPK tanah terhadap tanaman jagung manis, mempelajari pengaruh pemupukan N terhadap ketersediaan NPK tanah terhadap tanaman
\end{abstract}


jagung manis, dan mempelajari pengaruh interaksi antara biochar dan pemupukan $\mathrm{N}$ terhadap ketersediaan NPK tanah terhadap tanaman jagung manis. Penelitian ini dilakukan di Lahan Lapang Terpadu Unila, Bandar Lampung dari Januari sampai September 2017. Penelitian ini dirancang dengan Rancangan Acak Lengkap (RAL) faktorial dengan dua faktor dan tiga ulangan. Faktor pertama adalah dosis biochar yaitu: $0 ; 2,5$ dan $5 \mathrm{tha}^{-1}$. Faktor kedua adalah dosis pupuk $\mathrm{N}$ yaitu $0 ; 45 ; 90$ dan $135 \mathrm{~kg} \mathrm{~N} \mathrm{ha}^{-1}$. Homogenitas ragam data diuji dengan Uji Bartlett dan aditivitas data diuji dengan Uji Tukey. Data diolah dengan analisis ragam dan dilanjutkan dengan Uji BNJ pada taraf nyata 1\%. Hasil penelitian menunjukkan bahwa pemberian biochar berpengaruh sangat nyata terhadap ketersediaan hara N, P dan K dalam tanah, berpengaruh nyata terhadap kadar C-organik tanah dan tidak berpengaruh nyata terhadap $\mathrm{pH}$ tanah, pemupukan $\mathrm{N}$ berpengaruh sangat nyata terhadap ketersediaan hara N, P , K dan $\mathrm{pH}$ tanah dan tidak berpengaruh nyata terhadap kadar C-organik tanah, selain itu terdapat interaksi sangat nyata antara pemberian biochar dan pemupukan $\mathrm{N}$ terhadap ketersediaan hara $\mathrm{N}$ dan $\mathrm{K}$, namun tidak berinteraksi nyata terhadap kadar $\mathrm{P}$ dalam tanah dan dosis optimum pemberian biochar adalah 2,5 $\mathrm{t} \mathrm{ha}^{-1}$, sedangkan dosis pupuk $\mathrm{N}$ adalah 45 dan $90 \mathrm{~kg} \mathrm{~N} \mathrm{ha}^{-1}$

Kata kunci: biochar, jagung manis, ketersediaan hara N, P dan K dan pemupukan N.

\section{PENDAHULUAN}

Jagung manis (Zea mays L.) merupakan komoditas pangan penting kedua setelah padi. Tanaman ini memiliki nilai jual tinggi karena sebagian masyarakat Indonesia suka mengkonsumsi jagung manis sebagai campuran dalam masakan bahkan dikonsumsi langsungdengan cara direbus dan bahan baku pakan ternak. Permintaan pasar pada saat ini terhadap jagung manis terus meningkat seiring dengan munculnya pasar-pasar modern yang senantiasa membutuhkannya dalam jumlah cukup besar. Namun, permintaan yang tinggi ini tidak diimbangi dengan ketersediaaan sehingga mengakibatkan permintaan tersebut tidak terpenuhi. Hal ini tentunya memerlukan upaya untuk peningkatan kualitas dan kuantitas hasil dengan tetap menjaga kelestarian lingkungan (Lestari et al., 2010).

Saat ini bahan organik yang rendah dalam tanah disebabkan oleh adanya pertanian tradisional. Pertanian tradisional hanya memanfaatkan unsur hara yang berasal dari bahan organik tersebut. Asupan nutrisi yang terbatas dalam tanah melalui pupuk menyebabkan ketersediaan bahan organik tanah yang rendah. Selain pemberian pupuk, diperlukan penambahan bahan organik melalui bahan pembenah tanah. Salah satu bahan pembenah tanah yang dapat digunakan yaitu biochar. Biochar merupakan produk sampingan dari hasil pembakaran limbah pertanian dan perkebunan seperti potongan ranting pohon, tandan kelapa sawit, tongkol jagung, batang singkong dan hasil produk pertanian yang dibuat dengan memaparkan biomassa menggunakan suhu tinggi tanpa adanya oksigen sehingga dapat dihasilkan gas sintetik dan bio-oil serta arang hayati yang dikenal dengan biochar (Haryadi, 2016). Biochar memiliki manfaat diantaranya yaitu dapat meningkatkan kesuburan tanah, mampu menyerap serta menyimpan karbon (C) dalam tanah dan menjaga keseimbangan ekosistem tanah dan bisa bertindak 
sebagai pupuk sehingga dapat meningkatkan pertumbuhan dan hasil tanaman dengan menyediakan dan mempertahankan hara (Glasser, et al., 2002).

Biochar menjadi bahan pembenah tanah karena memiliki kemampuan untuk mempertahankan keberadaan unsur hara yang berguna bagi tanaman dan mampu mengurangi terjadinya aliran permukaan akibat air berlebih. Dua hal penting dalam pemanfaatan biochar sebagai bahan pembenah tanah adalah kecenderungannya untuk berikatan dengan unsur hara dan persisten yang tinggi (Haryadi, 2016).

Niswati (2013) dalam Harini (2017) melaporkan penelitian yang dilakukan menggunakan media tanam yang sama dengan menggunakan tanaman jagung sebagai indikator menunjukkan bahwa penambahan 5\% biochar ke dalam tanah telah meningkatkan kesuburan tanah dan mempengaruhi pertumbuhan dan serapan hara oleh tanaman jagung. Keterbatasan $\mathrm{N}$ merupakan alasan utama berkurangnya respon tanaman dengan pemberian biochar dalam jumlah yang banyak. Penelitian yang telah dilakukan Gani (2009) menunjukkan bahwa pemberian biochar dengan dosis 10, 50 dan 100 tha${ }^{1}$ dan tanpa tambahan pupuk $\mathrm{N}$ pada tanaman radish dan kualitas tanahnya menunjukkan penurunan hasil tanaman bahkan sampai pemberian dosis $100 \mathrm{tha}^{-1}$. Namun interaksi terlihat nyata antara biochar dengan pupuk N. Penambahan biochar dan pupuk N terjadi peningkatan hasil yang lebih besar sehingga peran biochar dalam meningkatkan efisiensi pemupukan $\mathrm{N}$ pada tanaman.
Menurut Gani (2009), pengaplikasian biochar (arang kayu yang didapat dari biomassa) ke dalam tanah dianggap sebagai suatu pendekatan yang baru dan unik untuk menjadikan suatu penampung $(\operatorname{sink})$ bagi $\mathrm{CO}_{2}$ udara dalam jangka panjang pada ekosistem darat. Dari perspektif iklim, penggunaan biochar dipercaya sebagai karbon negatif yang mengurangi konsentrasi karbon di atmosfer, beberapa mekanisme yang terjadi yaitu : 1) Siklus hidup pada tumbuhan terdapat karbon yang terkubur dalam tanah; 2) Biochar dalam tanah berperan dalam mengurangi penggunaan pupuk dan kebutuhan irigasi, dan 3) Gas metana yang dihasilkan dari limbah pertanian lebih berbahaya dibandingkan $\mathrm{CO}_{2}$ menjadi penyebab gas rumah kaca dan terjadi penurunan pembusukan sisa-sisa tanaman.

Pemupukan adalah salah satu usaha untuk meningkatkan kembali hara dalam tanah dengan cara menambahkan unsur-unsur hara yang dibutuhkan oleh tanaman untuk peningkatan produksi dan mutu hasil tanaman. Unsur hara N termasuk unsuryang dibutuhkan dalam jumlah paling banyak. Sumber unsur $\mathrm{N}$ dapat diperoleh dari bahan organik, mineral tanah, maupun penambahan dari pupuk organik (BPTP kaltim, 2015). Hara $\mathrm{N}$ dari pupuk Urea mengandung $\mathrm{N}$ tinggi yaitu sekitar 45-46\%. Unsur hara $\mathrm{N}$ berperan dalam pembentukan daun, namun unsur ini mudah tercuci sehingga diperlukan bahan organik dan bahan pembenah tanah untuk meningkatkan daya menahan air dan kation-kation tanah

(Ramadhani, et al., 2016).

Bila biochar digunakan sebagai pembenah tanah bersama pupuk $\mathrm{N}$, kedua bahan ini dapat 
meningkatkan produktivitas, retensi dan ketersediaan hara dalam tanah bagi tanaman (Gani, 2009). Oleh karena itu, pengaruh pengkombinasian biochar dan pupuk $\mathrm{N}$ diharapkan mampu memperbaiki ketersediaan NPK pada pertanaman jagung manis (Zea mays L.).

Penelitian ini bertujuan untuk (1) mengetahui pengaruh biochar terhadap ketersediaan NPK tanah terhadap tanaman jagung manis (Zea mays L.), (2) mengetahui pengaruh pemupukan Nitrogen terhadap ketersediaan NPK tanah pada tanaman jagung manis (Zea mays L.), (3) mengetahui interaksi antara biochar dan pemupukan Nitrogen terhadap ketersediaan NPK tanah pada tanaman jagung manis (Zea mays L.).

\section{BAHAN DAN METODE}

Penelitian ini dilaksanakan di lahan laboratorium lapang Terpadu Fakultas Pertanian, Universitas Lampung dari bulan Januari sampai September 2017. Analisis tanah dilakukan di laboratorium Ilmu Tanah, Fakultas Pertanian, Universitas Lampung.

Bahan yang digunakan pada penelitian ini antara lain: benih jagung manis Jawara Bimmo, batang singkong, pupuk Urea, pupuk SP-36, pupuk KCl, pestisida Regent, Ridomil 35 SD, amplop coklat, dan polibag. Alat yang digunakan pada penelitian ini antara lain: cangkul, mortal, hand sprayer, kaleng, oven, timbangan, meteran, sabit, saringan $500 \mu \mathrm{m}$, saringan $1 \mathrm{~mm}$, saringan $2 \mathrm{~mm}$, spektrofotometer, AAS, flamefotometer dan centrifius.

Penelitian ini disusun menggunakan Rancangan Acak Lengkap (RAL) faktorial. Perlakuan yang diuji terdiri dari dua faktor yaitu: (1) Faktor pertama adalah dosis pupuk biochar yakni: $\mathrm{B} 0=0 \mathrm{tC} \mathrm{ha}^{-1}, \mathrm{~B} 1=2,5$ t C ha-1, B2 $=5$ t C ha-1. (2) Faktor kedua adalah dosis pupuk pupuk $\mathrm{N}$ yakni: $\mathrm{N} 0=0 \mathrm{~kg} \mathrm{~N} \mathrm{ha}^{-1}, \mathrm{~N} 1=$ $45 \mathrm{~kg} \mathrm{~N} \mathrm{ha}^{-1}, \mathrm{~N} 2=90 \mathrm{~kg} \mathrm{~N} \mathrm{ha}^{-1}, \mathrm{~N} 3: 135 \mathrm{~kg} \mathrm{~N} \mathrm{ha}^{-1}$. Homogenitas ragam antar perlakuan diuji dengan uji Bartlett dan kenambahan (aditivitas) data diuji dengan uji Tukey. Jika asumsi terpenuhi, data dianalisis dengan sidik ragam untuk pendugaan ragam galat dan dilanjutkan dengan uji Beda Nyata Jujur pada taraf $1 \%$.

Pelaksanaan pada penelitian ini dilakukan dengan tahapan sebagai berikut pertama, pembuatan biochar dengan bahan baku kayu batang singkong. Kayu batang singkong dipotong kecil-kecil kira-kira $2 \mathrm{~cm}$. Selanjutnya kayu tersebut dikeringkan dalam oven pada suhu $65^{\circ} \mathrm{C}$ selama 48 jam. Sebuah kaleng logam yang tertutup dengan memiliki lubang kecil diisi dengan bahan kayu singkong, ditimbang dan dimasukkan ke dalam tungku. Kemudian kaleng tersebut dipanaskan pada suhu $300^{\circ} \mathrm{C}$ selama 4 jam. Setelah dingin dibuka dan dihaluskan dan disaring dengan ayakan $1 \mathrm{~mm}$.

Kemudian persiapan tanah yang sudah dibersihkan dari akar yang terbawa, dikeringudarakan dan diayak dengan ayakan $2 \mathrm{~mm}$ dan dilakukan analisis tanah awal. $10 \mathrm{~kg}$ tanah dimasukkan ke dalam polibag sebanyak 36 pot dan disusun dilahan terpadu Universitas Lampung.

Selanjutnya pemberian biochar ke dalam tanah dengan mencampurkan secara merata ke dalam tanah seminggu sebelum tanah diberikan dengan dosis perlakuan. Tanah yang sudah bercampur dengan biochar, kadar air dipertahankan pada keadaan pada kapasitas lapang. Biochar diaplikasikan dengan dosis 
Tabel 1. Analisis dan Kriteria Sifat Kimia Tanah Awal Polinela dan Biochar

\begin{tabular}{lcccc}
\hline \multicolumn{1}{c}{ Parameter } & $\begin{array}{c}\text { Tanah Polinela } \\
(* *)\end{array}$ & $\begin{array}{c}\text { Kriteria } \\
(*)\end{array}$ & $\begin{array}{c}\text { Biochar } \\
(* *)\end{array}$ & $\begin{array}{c}\text { Kriteria } \\
(*)\end{array}$ \\
\hline N-total $(\%)$ & 0,06 & Sangat Rendah & 0,84 & Sangat Tinggi \\
P-tersedia $(\mathrm{ppm})$ & 3,49 & Sangat Rendah & - & - \\
K-dd $\left(\mathrm{cmol} \mathrm{kg}^{-1}\right)$ & 0,12 & Rendah & - & - \\
C-organik $(\%)$ & 1,08 & Rendah & 31,28 & Sangat Tinggi \\
$\mathrm{pH} \mathrm{H} \mathrm{H}_{2} \mathrm{O}(1: 2,5)$ & 6,37 & Agak masam & 8,4 & Agak Alkalis \\
\hline
\end{tabular}

Keterangan : *balittanah.litbang.deptan.go.id (2005) ; ${ }^{* *}$ Laboratorium Ilmu Tanah Universitas Lampung (2017)

Tabel 2. Pengaruh Interaksi Pemberian Biochar dan Pemupukan N terhadap N-total Tanah.

\begin{tabular}{ccccc}
\hline \multirow{2}{*}{ Biochar $\left(\mathrm{t} \mathrm{ha}^{-1}\right)$} & 0 & \multicolumn{4}{c}{ Pemupukan N $\left(\mathrm{kg} \mathrm{N} \mathrm{ha}^{-1}\right)$} \\
\cline { 2 - 5 } & $0,08 \mathrm{a}$ & $0,09 \mathrm{ab}$-total $(\%)$ & 90 & 135 \\
\cline { 2 - 5 } & $\mathrm{A}$ & $\mathrm{A}$ & $0,14 \mathrm{~b}$ & $0,08 \mathrm{a}$ \\
2,5 & $0,10 \mathrm{a}$ & $0,11 \mathrm{ab}$ & $\mathrm{A}$ & $\mathrm{A}$ \\
& $\mathrm{A}$ & $\mathrm{AB}$ & $0,13 \mathrm{ab}$ & $0,15 \mathrm{~b}$ \\
5 & $0,09 \mathrm{a}$ & $0,14 \mathrm{~b}$ & $\mathrm{~A}$ & $\mathrm{~B}$ \\
& $\mathrm{~A}$ & $\mathrm{~B}$ & $\mathrm{~A}$ & $\mathrm{~A} \mathrm{~b}$ \\
\hline BNJ 1\% & 0,04 & $\mathrm{~B}$ \\
\hline Keterangan : Angka-angka yang diikuti huruf yang sama tidak berbeda nyata dan huruf kecil dibaca arah horizontal, huruf
\end{tabular}

\section{HASIL DAN PEMBAHASAN}

Berdasarkan penelitian yang telah dilaksanakan diperoleh hasil analisis awal sifat kimia tanah disajikan pada Tabel 1. Tabel 1 menunjukkan bahwa tanah Ultisol yang digunakan pada penelitian ini memiliki C-organik yaitu 1,08\% (rendah), K-dd yaitu $0,12 \mathrm{cmol} \mathrm{kg}^{-1}$ (sangat rendah), $\mathrm{N}$-total yaitu 0,06\% (rendah), P-tersedia yaitu 3,49 ppm (sangat rendah) dan reaksi tanah $\left(\mathrm{pH} \mathrm{H}_{2} \mathrm{O}\right)$ yaitu 6,37 (agak masam).

Tanah dengan $\mathrm{pH}$ yang agak masam juga akan mempengaruhi kemampuan tanah dalam menjerap dan menukar kation. Pengelolaan tanah yang masam harus dilakukan dengan memperhatikan sifat-sifat kimia di atas. Usaha yang dapat dilakukan untuk memperbaiki $\mathrm{pH}$ tanah yang agak masam adalah dengan menaikkan nilai $\mathrm{pH}$ sampai dengan nilai yang dapat menjamin perbaikan sifat-sifat tanah lain. Salah satunya adalah dengan menambahkan biochar dan pemupukan $\mathrm{N}$.

Biochar yang digunakan dalam penelitian ini berasal dari batang singkong. Biochar memiliki Corganik yaitu 31,28\% (sangat tinggi), N-total yaitu 0,84\% (sangat tinggi), dan reaksi tanah $(\mathrm{pH})$ yaitu 8,4 (agak alkalis). Hal ini sesuai dengan yang telah diungkapkan oleh Lehmann dan Joseph (2009) menyatakan bahwa karakteristik sifat kimia dan kualitas 
biochar sangat ditentukan dari bahan asal pembuat biochar itu sendiri dan bermanfaat untuk meningkatkan kualitas tanah sebagai media tumbuh tanaman.

\section{N-total Tanah}

Kadar N-total tanah dipengaruhi oleh interaksi pemberian biochar dan pemupukan N. Tabel 2 menunjukkan pada tanpa pemberian biochar, kadar $\mathrm{N}$ antara pada pemupukan $\mathrm{N}$ dosis 0 dan $135 \mathrm{~kg} \mathrm{~N}$ ha $^{-1}$ tidak berbeda nyata dengan dosis $45 \mathrm{~kg} \mathrm{~N} \mathrm{ha}^{-1}$ tetapi kandungan menurun secara nyata pada pemupukan $\mathrm{N} 135 \mathrm{~kg} \mathrm{Nha}^{-1}$. Pada pemberian biochar dosis 2,5 $\mathrm{t} \mathrm{ha}^{-1}$, kadar $\mathrm{N}$ pada tanpa pemupukan $\mathrm{N}$ nyata lebih rendah dibandingkan pemupukan $\mathrm{N}$ dosis $135 \mathrm{~kg} \mathrm{~N} \mathrm{ha}{ }^{-1}$, tetapi tampak tidak berbeda nyata dengan kadar $\mathrm{N}$ pada dosis 45 dan $90 \mathrm{~kg} \mathrm{~N} \mathrm{ha}^{-1}$. Pada pemberian biochar dosis $5 \mathrm{t} \mathrm{ha}^{-1}$, kadar $\mathrm{N}$ pada tanpa pemupukan N nyata lebih rendah daripada pemupukan
$\mathrm{N}$ dosis $135 \mathrm{~kg} \mathrm{~N} \mathrm{ha}^{-1}$, tetapi tidak berbeda nyata dengan pemupukan $\mathrm{N}$ dosis 45 dan $90 \mathrm{~kg} \mathrm{~N} \mathrm{ha}^{-1}$.

Tabel 2 menunjukkan pada pemberian biochar nyata dapat meningkatkan kadar $\mathrm{N}$ pada dosis 45 dan 135

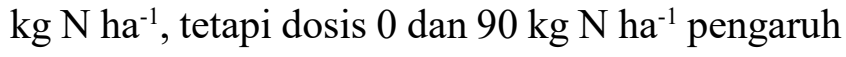
pemberian biochar tidak nyata. Pada pemupukan N dosis $45 \mathrm{~kg} \mathrm{~N} \mathrm{ha}^{-1}$, kadar $\mathrm{N}$ pada tanpa biochar lebih rendah daripada pemberian biochar dosis $5 \mathrm{tha}^{-1}$ ,tetapi tidak berbeda nyata dengan pemberian biochar dosis 2,5 t ha-1. Pada pemupukan $\mathrm{N}$ dosis $135 \mathrm{~kg} \mathrm{~N}$ ha $^{-1}$, kadar $\mathrm{N}$ pada tanpa biochar dan nyata lebih rendah dibandingkan dengan pemberian biochar dosis $5 \mathrm{t} \mathrm{ha}^{-1}$ sementara itu kadar $\mathrm{N}$ antara pemberian biochar dosis 2,5 tha $\mathrm{t}^{-1}$ dan $5 \mathrm{tha}^{-1}$ tidak berbeda nyata.

\section{P-tersedia Tanah}

Kadar P-tersedia hanya dipengaruhi oleh pemberian biochar. Tabel 3 menunjukkan bahwa

Tabel 3. Pengaruh pemberian biochar terhadap P-tersedia Tanah.

\begin{tabular}{cc}
\hline Pemberian biochar $\left(\mathrm{tha}^{-1}\right)$ & P-tersedia $(\mathrm{ppm})$ \\
\hline 0 & $8,78 \mathrm{a}$ \\
2,5 & $11,03 \mathrm{~b}$ \\
5 & $12,72 \mathrm{~b}$ \\
\hline BNJ 1\% & 2,01 \\
\hline
\end{tabular}

Keterangan : Angka-angka yang dikuti huruf yang sama tidak berbeda nyata taraf uji BNJ 1\%.

Tabel 4. Pengaruh Pemupukan N terhadap P-tersedia Tanah.

\begin{tabular}{cc}
\hline Pemupukan N $\left(\mathrm{kg} \mathrm{ha}^{-1}\right)$ & P-tersedia $(\mathrm{ppm})$ \\
\hline 0 & $6,53 \mathrm{a}$ \\
45 & $11,93 \mathrm{bc}$ \\
90 & $14,42 \mathrm{c}$ \\
135 & $10,50 \mathrm{~b}$ \\
\hline BNJ $1 \%$ & 2,73 \\
\hline
\end{tabular}

Keterangan : Angka-angka yang dikuti huruf yang sama tidak berbeda nyata taraf uji BNJ 1\%. 
Tabel 5. Pengaruh Interaksi Pemberian Biochar dan Pemupukan N terhadap K-dd Tanah

\begin{tabular}{|c|c|c|c|c|}
\hline \multirow{3}{*}{ Biochar $\left(\mathrm{t} \mathrm{ha}^{-1}\right)$} & \multicolumn{4}{|c|}{ Pemupukan N $\left(\mathrm{Kg} \mathrm{N} \mathrm{ha}^{-1}\right)$} \\
\hline & 0 & 45 & 90 & 135 \\
\hline & \multicolumn{4}{|c|}{ K-dd (cmol kg) } \\
\hline \multirow[t]{2}{*}{0} & $0,36 \mathrm{~b}$ & $0,38 \mathrm{~b}$ & $0,31 \mathrm{a}$ & $0,21 \mathrm{a}$ \\
\hline & A & A & A & A \\
\hline \multirow{2}{*}{2,5} & $0,35 \mathrm{a}$ & $0,29 \mathrm{a}$ & $0,32 \mathrm{a}$ & $0,36 \mathrm{a}$ \\
\hline & A & A & A & B \\
\hline \multirow[t]{2}{*}{5} & $0,50 \mathrm{c}$ & $0,36 \mathrm{ab}$ & $0,40 \mathrm{bc}$ & $0,28 \mathrm{a}$ \\
\hline & $\mathrm{B}$ & A & A & $\mathrm{AB}$ \\
\hline BNJ 1\% & \multicolumn{4}{|c|}{0,10} \\
\hline
\end{tabular}

Keterangan : Angka-angka yang diikuti huruf yang sama tidak berbeda nyata dan huruf kecil dibaca arah horizontal, huruf kapital dibaca arah vertikal taraf uji BNJ 1\%

kadar P-tersedia pada pemberian biochar dosis 2,5 t $\mathrm{ha}^{-1}$ tidak berbeda nyata daripada pemberian biochar dosis $5 \mathrm{t} \mathrm{ha}^{-1}$, sedangkan pada tanpa pemberian biochar nyata lebih rendah dibandingkan perlakuan lainnya.

Kadar P-tersedia hanya dipengaruhi oleh pemupukan N. Tabel 4 menunjukkan bahwa kadar Ptersedia pada tanpa pemupukan $\mathrm{N}$ berbeda nyata dibandingkan pemupukan $\mathrm{N}$ dosis 45, 90 dan $135 \mathrm{~kg}$ $\mathrm{N} \mathrm{ha}^{-1}$. Pada pemupukan $\mathrm{N}$ dosis $45 \mathrm{~kg} \mathrm{~N} \mathrm{ha}^{-1}$ tidak berbeda nyata dengan pemupukan $\mathrm{N} 90 \mathrm{~kg} \mathrm{~N} \mathrm{ha-1}$ dan tidak berbeda nyata dengan dosis $135 \mathrm{~kg} \mathrm{~N} \mathrm{ha}^{-1}$. Pada pemupukan $\mathrm{N}$ dosis $90 \mathrm{~kg} \mathrm{~N} \mathrm{ha}^{-1}$ nyata lebih tinggi dibandingkan perlakuan lainnya.

\section{K-dd Tanah}

Kadar K-dd tanah dipengaruhi oleh interaksi pemberian biochar dan pemupukan N. Tabel 5 menunjukkan bahwa pemupukan 45 dan $90 \mathrm{~kg} \mathrm{~N} \mathrm{ha}^{-}$ ${ }^{1}$, pada semua dosis pemberian biochar tidak berbeda nyata terhadap kadar K-dd tanah. Pada tanpa pemupukan $\mathrm{N}$, kadar K-dd tanah pada pemberian biochar dosis 5 tha $^{-1}$ nyata lebih tinggi dibandingkan pemberian biochar dosis 2,5 tha ${ }^{-1}$ dan tanpa biochar. Pada pemupukan $\mathrm{N}$ dosis $135 \mathrm{~kg} \mathrm{~N}$ ha $^{-1}$, kadar K-dd tanah pada pemberian biochar dosis 5 tha $^{-1}$ dan tanpa pemberian biochar nyata lebih rendah dibandingkan pemberian biochar 2,5 tha-1 dan perlakuan lainnya.

Tabel 5 menunjukkan pada tanpa pemberian biochar, kadar K-dd tanah pada pemupukan $\mathrm{N}$ dosis 90 dan $135 \mathrm{~kg} \mathrm{~N} \mathrm{ha}^{-1}$ tidak berbeda nyata dan lebih rendah dibandingkan pemupukan $\mathrm{N}$ dosis $45 \mathrm{~kg} \mathrm{~N}$ ha- $^{-}$ ${ }^{1}$ dan tanpa pemupukan N. Pada pemberian biochar dosis 2,5 t ha-1 ${ }^{-1}$ kadar K-dd tanah pada semua dosis pemupukan $\mathrm{N}$ tidak berbeda nyata dan meningkatkan kadar K-dd tanah. pada pemberian biochar dosis $5 \mathrm{t}$ ha $^{-1}$, kadar K-dd tanah pada tanpa pemupukan $\mathrm{N}$ tidak berbeda nyata dengan pemupukan $\mathrm{N}$ dosis $90 \mathrm{~kg} \mathrm{~N}$ $\mathrm{ha}^{-1}$, tetapi pemberian biochar dosis $5 \mathrm{t} \mathrm{ha}^{-1}$, kadar $\mathrm{K}$-dd tanah pada tanpa pemupukan $\mathrm{N}$ berbeda nyata dengan pemupukan $\mathrm{N}$ dosis 45 dan $135 \mathrm{~kg} \mathrm{~N} \mathrm{ha}^{-1}$.

\section{C-organik Tanah}

Kadar C-organik tanah dipengaruhi oleh interaksi pemberian biochar dan pemupukan N. Tabel 6 menunjukkan bahwa pada pemupukan $\mathrm{N}$ dosis 0 
Tabel 6. Pengaruh Interaksi Pemberian Biochar dan Pemupukan N terhadap C-organik

\begin{tabular}{|c|c|c|c|c|}
\hline \multirow{3}{*}{ Biochar $\left(\mathrm{t} \mathrm{ha}^{-1}\right)$} & \multicolumn{4}{|c|}{ Pemupukan N $\left(\mathrm{kg} \mathrm{N} \mathrm{ha}^{-1}\right)$} \\
\hline & 0 & 45 & 90 & 135 \\
\hline & \multicolumn{4}{|c|}{ C-organik (\%) } \\
\hline \multirow[t]{2}{*}{0} & $1,29 \mathrm{ab}$ & $1,61 \mathrm{ab}$ & $1,81 \mathrm{~b}$ & $1,10 \mathrm{a}$ \\
\hline & A & A & B & A \\
\hline \multirow[t]{2}{*}{2,5} & $1,53 \mathrm{a}$ & $1,69 \mathrm{a}$ & $1,41 \mathrm{a}$ & $1,94 \mathrm{a}$ \\
\hline & A & A & $\mathrm{AB}$ & $\mathrm{B}$ \\
\hline \multirow[t]{2}{*}{5} & $1,56 \mathrm{a}$ & $1,38 \mathrm{a}$ & $1,20 \mathrm{a}$ & $1,70 \mathrm{a}$ \\
\hline & A & A & A & $\mathrm{B}$ \\
\hline BNJ 1\% & \multicolumn{4}{|c|}{0,53} \\
\hline
\end{tabular}

Keterangan : Angka-angka yang diikuti huruf yang sama tidak berbeda nyata dan huruf kecil dibaca arah horizontal, huruf kapital dibaca arah vertikal taraf uji BNJ $1 \%$

Tabel 7. Pengaruh Pemupukan N terhadap pH Tanah

\begin{tabular}{cc}
\hline Pemupukan N $\left(\mathrm{kg} \mathrm{N} \mathrm{ha}^{-1}\right)$ & $\mathrm{pH}\left(\mathrm{H}_{2} \mathrm{O}\right)$ \\
\hline 0 & $5,43 \mathrm{c}$ \\
45 & $4,69 \mathrm{ab}$ \\
90 & $4,44 \mathrm{a}$ \\
135 & $4,50 \mathrm{ab}$ \\
\hline BNJ 1\% & 0,46 \\
\hline
\end{tabular}

Keterangan : Angka-angka yang dikuti huruf yang sama tidak berbeda nyata taraf uji BNJ 1\%.

dan $45 \mathrm{~kg} \mathrm{~N} \mathrm{ha}^{-1}$, kadar C-organik pada semua dosis pemberian biochar tidak berbeda nyata. Pada pemupukan $\mathrm{N}$ dosis $90 \mathrm{~kg} \mathrm{~N} \mathrm{ha}^{-1}$, kadar C-organik pada tanpa pemberian biochar lebih tinggi dibandingkan pemberian biochar dosis $5 \mathrm{t} \mathrm{ha}^{-1}$ dan pemupukan $\mathrm{N}$ dosis $135 \mathrm{~kg} \mathrm{~N}$ ha $^{-1}$ dengan tanpa pemberian biochar lebih rendah dibandingkan pemberian biochar dosis 2,5 dan $5 \mathrm{tha}^{-1}$.

Tabel 6 menunjukkan bahwa pada tanpa pemberian biochar, kadar C-organik pada

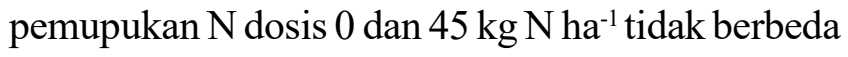
nyata dengan pemupukan $\mathrm{N}$ dosis $90 \mathrm{~kg} \mathrm{~N} \mathrm{ha}^{-1}$. Namun tanpa pemberian biochar, kadar C-organik pada pemupukan $\mathrm{N}$ dosis $90 \mathrm{~kg} \mathrm{Nha}^{-1}$ berbeda nyata dengan pemupukan $\mathrm{N}$ dosis $135 \mathrm{~kg} \mathrm{~N}$ ha $^{-1}$. Pada pemberian biochar dosis 2,5 dan $5 \mathrm{t} \mathrm{ha}^{-1}$, pada semua dosis pemupukan $\mathrm{N}$ tidak berpengaruh nyata terhadap kadar C-organik.

\section{pH Tanah}

Kemasaman tanah hanya dipengaruhi oleh pemupukan N. Tabel 7 menunjukkan bahwa kadar $\mathrm{pH}$ tanah antara pemupukan $\mathrm{N}$ dosis 45 dan $135 \mathrm{~kg} \mathrm{~N} \mathrm{ha}^{-}$ ${ }^{1}$ tidak berbeda nyata dengan pemupukan $\mathrm{N}$ dosis 90 $\operatorname{kg~} \mathrm{N} \mathrm{ha}^{-1}$, tetapi berbeda nyata dengan tanpa pemupukan $\mathrm{N}$ dan nyata lebih tinggi dibandingkan perlakuan lainnya. 


\section{KESIMPULAN}

Berdasarkan hasil penelitian menunjukkan bahwa (1) pemberian biochar berpengaruh sangat nyata terhadap ketersediaan hara N, P dan K dalam tanah, berpengaruh nyata terhadap kadar C-organik tanah dan tidak berpengaruh nyata terhadap $\mathrm{pH}$ tanah,(2) pemupukan $\mathrm{N}$ berpengaruh sangat nyata terhadap ketersediaan hara $\mathrm{N}, \mathrm{P}, \mathrm{K}$ dan $\mathrm{pH}$ tanah dan tidak berpengaruh nyata terhadap kadar C-organik tanah, (3) terdapat interaksi sangat nyata antara pemberian biochar dan pemupukan $\mathrm{N}$ terhadap ketersediaan hara $\mathrm{N}$ dan K, namun tidak berinteraksi nyata terhadap kadar P dalam tanah, (4) dosis optimum pemberian biochar adalah 2,5 t ha ${ }^{-1}$, sedangkan dosis pupuk $\mathrm{N}$ adalah 45 dan $90 \mathrm{~kg} \mathrm{~N} \mathrm{ha}^{-1}$.

\section{SARAN}

Berdasarkan penelitian yang telah dilakukan, saran yang dapat diajukan adalah: Pembuatan biochar menggunakan bahan baku lain seperti: tongkol jagung, pelepah daun jagung, pelepah daun kelapa sawit, batang jagung manis dan batang singkong sehingga diketahui BB (Bahan Baku) terbaik yang dapat digunakan sebagai biochar dan penentuan dosis yang diberikan pada tanah penelitian. Penelitian selanjutnya disarankan untuk dilakukan pemberian biochar dengan dosis terbaik yaitu 2,5 dan 5 tha $^{-1}$ untuk memperbaiki sifat kimia tanah dengan meningkatkan ketersediaan hara di dalam tanah seperti kadar N-total, kadar Ptersedia, kadar K-dd dan kadar C-organik yang tinggi pada tanah penelitian sebelumnya. Pemupukan $\mathrm{N}$ dilakukan dengan pemberian dosis terbaik antara dosis
45 dan $90 \mathrm{~kg} \mathrm{~N} \mathrm{ha}^{-1}$ untuk meningkatkan ketersediaan hara N, P dan K pada tanah penelitian dilahan lapangan terpadu sehingga mendukung pertumbuhan dan perkembangan tanaman jagung manis dan tanaman pangan lainnya.

\section{DAFTAR PUSTAKA}

Balai Pengkajian Teknologi Pertanian kaltim. 2015.Teknologi Budidaya Jagung Manis. Diakases dari http://kaltim.litbang. pertanian.go.id/ind/index. php? option $=$ com. content\&view $=$ article\&id $=707 \&$ Itemid=59. Pada tanggal 15 Juli 2018.

Gani, A. 2009. Biochar Penyelamat Lingkungan. Balai Penelitian Tanaman Padi. Warta Penelitian dan Pengembangan Pertanian 31 : 15-16.

Glasser, B., J. Lehmann. dan W. Zech. 2002. Ameliorating physical and chemical properties of highly weathered soils in the tropics with charcoal-A review. Biology and Fertility of Soils. 35 : 219 - 230.

Harini, N.V. 2017. Pengaruh Pemberian Kombinasi Pupuk Organonitrofos dan Pupuk Kimia dengan Penambahan Biochar terhadap Aktivitas Mikroorganisme Tanah Selama Pertumbuhan Jagung Manis (Zea mays. L. Saccharata Sturt) Musim Tanam Kedua. (Thesis). Universitas Lampung. Bandar Lampung.

Haryadi,A. 2016. Pengaruh Residu Biochar Terhadap Pertumbuhan dan Serapan N dan K Tanaman Kedelai (Glycine max L.) pada Topsoil dan Subsoil Tanah Ultisol. (Skripsi). Universitas Lampung. Bandar Lampung. 
Lehmann, J. and S. Joseph. 2009. Biochar for Enviromental Management: Science and Technology. Earthscan-UK.

Lestari, A.P., S. Sarman, dan E. Indraswari. 2010. Substitusi Pupuk Anorganik dengan Kompos Sampah Kota Tanaman Jagung Manis ( Zea mays. L. Saccharata Sturt). Jurnal Penelitian Universitas Jambi Seri Sains 12(2) : 1-6.

Ramadhani, R., M. Roviq, dan M. Dawam. 2016. Pengaruh Sumber Pupuk Nitrogen dan Waktu Pemberian Urea pada Pertumbuhan dan Hasil Tanaman Jagung Manis (Zea mays. L. Saccharata Sturt). Jurnal Produksi Tanaman (4) : 8-15. 